\title{
BILHÕES DE ANOS EM UMA TELA DE COMPUTADOR
}

Bilhões de anos em uma semana. A instigante frase foi cunhada por alunos de geologia da Universidade Federal Rural do Rio de Janeiro para despertar a atenção das pessoas em geral sobre um ciclo de palestras, em janeiro de 2007. A abordagem situa precisamente a função do geocientista e das geociências nas sociedades modernas: estudar, entender e explicar, em palavras simples, a origem e padrões de evolução do planeta onde vivemos. A mesma imagem, bilhões de anos em uma tela de computador, pode ilustrar o papel de uma revista eletrônica como Terræ Didatica, que busca difundir conhecimentos geocientíficos sobre o planeta.

Para acompanhar o noticiário contemporâneo, um cidadão precisa ter conhecimentos sobre Ciências da Terra e relações entre a Terra e as sociedades humanas, temas cada vez mais complexos - que justificam a criação do Ano Internacional do Planeta Terra (2007-2009) - já que podem afetar até mesmo a sobrevivência da espécie no planeta. Como exemplo do conflito sociedade $X$ natureza, basta lembrar o triste episódio ocorrido em túnel de metrô em São Paulo. Ainda são mal conhecidas as proporções do acidente, mas foi alto o custo oriundo da má avaliação e gerenciamento de riscos. Experiente geólogo de empresa pública contratante das escavações destacou [documento do geólogo Kenzo Hori sobre acidente da Linha 4] que: "a natureza não tem culpa dos erros do homem"; este, geralmente, é quem provoca o desequilíbrio. Não basta conhecer pormenorizadamente características do subsolo, a dinâmica e as causas de fenômenos naturais, é preciso atualizar continuamente os dados obtidos em frentes de obras e, segundo ele, investir na formação dos jovens geólogos e engenheiros sobre a "difícil arte de construir túneis". Reaparece pois, nesse contexto trágico, a questão educacional.

Lançada ao final de 2005 pelo Instituto de Geociências da Unicamp, Terræ Didatica foi bem recebida pelos leitores. É provavel que a principal explicação desse sucesso seja o interesse despertado pelo ensinoaprendizagem das Ciências da Terra. A revista objetiva atender às comunidades de Geologia, Geografia e Educação, do Brasil e outros países, em particular a íbero-latino-americana.

\section{Este número}

O presente número de Terræ Didatica dá continuidade ao esforço de divulgar ações educacionais, fomentar novas experiências pedagógicas, estimular intercâmbio de metodologias de ensino e práticas educativas inovadoras, além de interligar o ambiente acadêmico com a divulgação das Ciências da Terra. Alargou-se o espectro de autores, em relação ao primeiro número, mediante participação de docentes e pesquisadores de várias universidades brasileiras que aceitaram a chamada de trabalhos e ajudaram a consolidá-la como periódico aberto.

A primeira comunicação resulta de palestra proferida pelo prof. F.F.M. de Almeida por ocasião de homenagens recebidas em diferentes 
cidades brasileiras durante 2004, atendendo a sucessivos lançamentos de livro publicado em sua homenagem.

O segundo trabalho sobre Geoestatística e o terceiro, sobre estruturas atectônicas, sintetizam conceitos especializados, ainda que introdutórios, de seus respectivos campos de conhecimento. $O$ artigo das estruturas dobradas registra fotos e esquemas da notável descoberta de feições dessa natureza na área urbana de Campinas, SP. As comunicações seguintes abordam conceitos especializados de Paleontologia e do ensino de Mineralogia por meio de recursos de Informática e da abordagem de minerais raros. Finalmente, as páginas eletrônicas de Terræ Didatica abrigamrelatos de reuniões 1 e 2 e 2004 e 2005 do Fórum Nacional de Cursos de Geologia. Com mais esta etapa, damos continuidade ao registro de uma série de reuniões importantes para aprimorar o ensino de Geologia no país.

Fazemos votos de que as comunicações aqui contidas sejam úteis e reiteramos o convite à comunidade a produzir materiais didáticos originais e utilizar sua criatividade para estender sua pesquisa na divulgação das Ciências da Terra. Estamos receptivos a acolher sugestões sobre outros modos de utilização deste espaço de difusão de idéias e propostas educativas. 